\title{
The analysis of egg and milk allergens in children patients
}

Li He*, Qin Yuan Chen

From Food Allergy and Anaphylaxis Meeting 2011

Venice, Italy. 17-19 February 2011

\section{Background}

To investigate the Status of children allergic toegg and milk.

\section{Methods}

Serum special IgE antibody (SIgE) levels against egg and milk allergens were detected by fluorescent ELISA.

\section{Results}

The positive rates of SIgE against the egg allergen and the milk allergen of children were $33.1 \%$ and $25.7 \%$, respectively. The positive rates of egg allergen in 0-3, 36 years group were significantly higher than those of 6 14 years group $(\mathrm{P}<0.05)$. The positive rates of milk allergen in $0-3$ years group were significantly higher than those of 3-6,6-14 years group $(\mathrm{P}<0.05)$.

\section{Conclusions}

The positive rates of egg and milk allergens in children were decrease as the age of children increased.

\section{Key words}

Egg, Milk, SIgE, Food allergy, Children

Submit your next manuscript to BioMed Central and take full advantage of:

- Convenient online submission

- Thorough peer review

- No space constraints or color figure charges

- Immediate publication on acceptance

- Inclusion in PubMed, CAS, Scopus and Google Scholar

- Research which is freely available for redistribution 